\title{
Assembly of 60S Ribosomal Subunits Is Perturbed in Temperature- Sensitive Yeast Mutants Defective in Ribosomal Protein L16
}

\author{
MICHELLE MORITZ,† BETH A. PULASKI, $\ddagger$ AND JOHN L. WOOLFORD, JR.* \\ Department of Biological Sciences, Carnegie Mellon University, Pittsburgh, Pennsylvania 15213
}

Received 22 May 1991/Accepted 28 August 1991

\begin{abstract}
Temperature-sensitive mutants defective in 60 S ribosomal subunit protein $\mathbf{L} 16$ of Saccharomyces cerevisiae were isolated through hydroxylamine mutagenesis of the RPL16B gene and plasmid shuffing. Two heatsensitive and two cold-sensitive isolates were characterized. The growth of the four mutants is inhibited at their restrictive temperatures. However, many of the cells remain viable if returned to their permissive temperatures. All of the mutants are deficient in 605 ribosomal subunits and therefore accumulate translational preinitiation complexes. Three of the mutants exhibit a shortage of mature 25S rRNA, and one accumulates rRNA precursors. The accumulation of rRNA precursors suggests that ribosome assembly may be slowed in this mutant. These phenotypes lead us to propose that mutants containing the rpll6b alleles are defective for $60 S$ subunit assembly rather than function. In the mutant carrying the $r p l 16 b-1$ allele, ribosomes initiate translation at the noncanonical codon AUA, at least on the rpll6b-1 mRNA, bringing to light a possible connection between the rate and the fidelity of translation initiation.
\end{abstract}

Most eukaryotic ribosomes are assembled from approximately 75 different ribosomal proteins (r-proteins) and 4 rRNA molecules in a process involving multiple cellular compartments. Newly synthesized r-proteins make their way from the cytoplasm to the nucleolus by a largely unknown mechanism and there associate with nascent rRNA. By analogy to Escherichia coli, the different r-proteins probably associate with assembling ribosomes in a strict order (reviewed in reference 60). Nearly all of the r-proteins assemble into subunits in the nucleolus. The ribosomes then are exported to the cytoplasm, where a few late-assembling proteins join them (72). The ribosomes then can assume their role as the protein-synthesizing machinery of the cell (reviewed in reference 70).

Very little is known about how eukaryotic ribosomes assemble, although maintaining the stoichiometry of ribosomal components appears to be important. In yeasts, r-proteins that are synthesized in excess of their counterparts are rapidly degraded, presumably in the absence of their ability to assemble into ribosomes $(14,39,65,71)$. Similarly, if the synthesis of a single r-protein or rRNA is terminated, most other proteins and RNAs of the same subunit of which that molecule is a part are synthesized and then degraded $(1,15,41,42,68,73)$. In these cases, turnover of ribosomal constituents may result upon disassembly of incorrectly or incompletely assembled subunits.

Temperature-sensitive mutants defective for ribosome assembly have also been isolated. In particular, cold-sensitive mutants have been a rich source of assembly mutants in bacteria, probably because ribosome assembly has a high activation energy $(6,21,44,46,62)$. Heat-sensitive assembly mutants have been isolated as well $(10,40,43,49,55)$. Many of these bacterial mutants exhibit defects in assembly of specific subunits, often concomitantly with the accumulation

\footnotetext{
* Corresponding author.

$\dagger$ Present address: Department of Biochemistry and Biophysics, University of California, San Francisco, San Francisco, CA 941430448.

$\ddagger$ Present address: Department of Immunology, University of Rochester, Rochester, NY 14642.
}

of aberrant or precursor ribosomal particles $(6,21,44,62)$. The mutations in some of these strains were determined to reside in r-protein genes $(10,40,44,49)$.

There are fewer examples of temperature-sensitive eukaryotic ribosome assembly mutants. Curiously, very few of those that have been isolated accumulate aberrant or precursor ribosomal particles, a phenomenon that has proved common in bacterial ribosome mutants. Descriptions of two temperature-sensitive mutants isolated from hamster cell lines have been published. One of these mutants is defective for processing of the $32 \mathrm{~S}$ rRNA precursor to produce $28 \mathrm{~S}$ rRNA. As a result, these cells lack wild-type levels of $60 \mathrm{~S}$ subunits. $40 \mathrm{~S}$ subunits are unaffected in this mutant (64). The second mutant's $60 \mathrm{~S}$ subunits are unstable and defective in either the elongation or termination step of translation in vitro (23). The gene products responsible for the phenotypes of these two mutants remain undefined.

Gritz and coworkers sought ribosome assembly mutants in Saccharomyces cerevisiae by screening for altered mobility of r-proteins on two-dimensional gels. One of these mutants was deficient in $40 \mathrm{~S}$ subunits (20). Surguchov and coworkers isolated a cold-sensitive mutant defective for $60 \mathrm{~S}$ subunit assembly (61). Some yeast mutants that have altered sensitivities to one or more of the antibiotics streptomycin, trichodermin, and cycloheximide are also cold sensitive and are defective in ribosome assembly $(4,7,58)$. Two mutants defective in rRNA processing have also been isolated but not extensively characterized $(1,15,68)$. The complementing gene for one of these mutants has been cloned, but its role in rRNA processing remains unknown (15). The identity of the genes bearing mutations in the other mutants mentioned above has not been determined. Finally, in a search for suppressors of a null allele of pabl, which encodes poly(A) binding protein in $S$. cerevisiae, Sachs and Davis isolated six cold-sensitive revertants that display a deficit of $60 \mathrm{~S}$ subunits $(53,54)$. One of these pseudorevertants bears a mutation in the r-protein gene RPL46 and another bears a mutation in a gene encoding a putative RNA helicase that may be involved in pre-rRNA processing $(53,54)$.

Some yeast r-proteins are highly conserved, with homologs in organisms as diverse as bacteria and humans (e.g., 
see references 17,36 , and 45 ). The degree of conservation of these proteins suggests that they play fundamental structural and/or functional roles in all ribosomes. For this reason, one might gain a better understanding of ribosome assembly and/or function by isolating mutants in which such a protein is defective. Here we describe the results of such an approach.

The yeast r-protein, L16, is a highly conserved, essential component of the $60 \mathrm{~S}$ subunit that is encoded by the duplicated genes $R P L 16 A$ and $R P L 16 B(37,52,65 \mathrm{a}, 74)$. The proteins encoded by these two genes differ by one amino acid residue but appear to be functionally equivalent, since either of these genes is sufficient for viability (52). We have shown previously that L16 is necessary for the assembly of $60 \mathrm{~S}$ subunits, but it appears to have no role in $40 \mathrm{~S}$ assembly $(41,52)$. This paper describes the isolation and characterization of temperature-sensitive mutants that are defective for L16 and 60S subunit assembly. One of these mutants also brings to light a possible connection between the rate and fidelity of translation initiation.

\section{MATERIALS AND METHODS}

Strains, plasmids, and media. Strains used in this study are described in Table 1 . The $E$. coli strain, HisB, was a gift of K. Struhl, Harvard Medical School. Yeast strains DBY1828 and DBY1829 were obtained from D. Botstein, Stanford University. Plasmid pHIS3CEN3 was provided by $\mathrm{B}$. Futcher, Cold Spring Harbor Laboratory (19).

YCp50-RPL16B was constructed by ligating a 3.2-kb $H$ indIII/BamHI fragment containing $R P L 16 B$ to YCp50 cut with HindIII and BamHI. Plasmid pHIS3CEN3-RPL16B was generated as follows. The ends of the 3.2-kb HindIIIBamHI RPL16B-containing fragment were filled by using the Klenow fragment of DNA polymerase I (a gift of W. Brown, Carnegie Mellon University). BamHI linkers were ligated to this fragment for another purpose. To construct $\mathrm{pHIS3}$ CEN3-RPL16B, EcoRI linkers were ligated to this BamHI fragment (which restored the BamHI sites as well), and the resulting fragment was ligated to EcoRI-linearized pHIS3CEN3.

JWY1402, a diploid heterozygous for disruptions of $R P L 16 A$ and $R P L 16 B$ (52), was transformed with YCp50$R P L 16 B$. Transformants were induced to sporulate by standard techniques (56). Tetrads were dissected, and spore clones bearing the rpll6a::TRP1 and rpll6b::LEU2 genomic alleles as well as YCp50-RPL16B were recovered. One of these spore clones (JWY1457) was chosen for use in plasmid-shuffling mutagenesis because it gave large numbers of transformants with tester plasmids (data not shown).

JWY1458, 1453, 1454, 1459, and 1460 were generated from JWY1457 by transformation with wild-type pHIS3CEN3$R P L 16 B$ or a pool of mutagenized pHIS3CEN3-RPL16B plasmids (see below) and subsequent isolation of $\mathrm{His}^{+}$ transformants that had lost YCp50-RPL16B by selection for $\mathrm{Ura}^{-}$cells on synthetic medium supplemented with 5-fluoroacetic acid (5-FOA) (5).

JWY1446, JWY1448, and JWY1449 were constructed as follows. Upon isolation of mutants JWY1453 and JWY1460, plasmids pHIS3CEN3-rpll6b-2 and pHIS3CEN3-rpll6b-3 were recovered from the strains and 3.2-kb EcoRI or BamHI fragments carrying the mutant $r p l 16 b-2$ and $r p l 16 b-3$ alleles were subcloned into the EcoRI or BamHI sites, respectively, of YIp5. The resulting YIp5-rpll6b-2 and YIp5-rpll6b-3 plasmids were linearized at a unique $B g l$ II site, $\sim 1.5 \mathrm{~kb}$ upstream of the rpll6b open reading frame (ORF), and used
TABLE 1. Strains used in this study

\begin{tabular}{|c|c|c|}
\hline Strain & Genotype & $\begin{array}{l}\text { Source or } \\
\text { reference }\end{array}$ \\
\hline E. coli HisB & hisB463 $\mathrm{F}^{\prime}($ tet $)$ & K. Struhl \\
\hline JWY1402 & 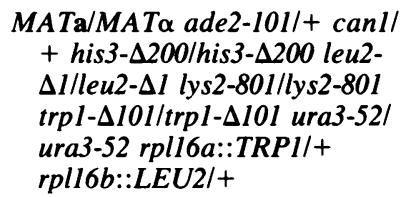 & 51 \\
\hline JWY1457 & 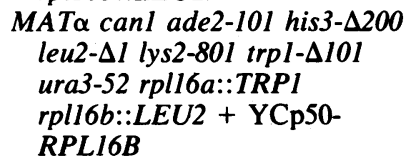 & This study \\
\hline JWY1458 & 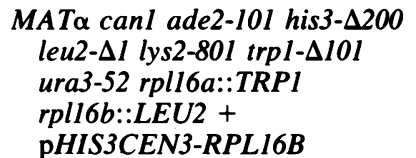 & This study \\
\hline JWY1453 & $\begin{array}{l}\text { MAT } \alpha \text { canl ade2-101 his3- } \Delta 200 \\
\text { leu2- } \Delta 1 \text { lys2-801 trpl- } \Delta 101 \\
\text { ura3-52 rpll6a::TRP1 } \\
\text { rpll6b::LEU2 }+ \\
\text { pHIS3CEN3-rpll6b-3 }\end{array}$ & This study \\
\hline JWY1454 & 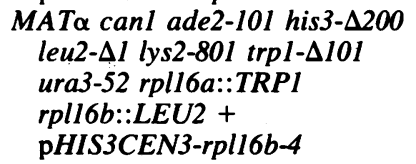 & This study \\
\hline JWY1459 & 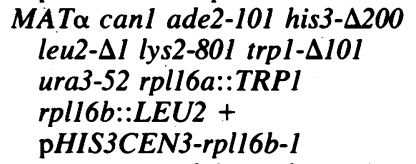 & This study \\
\hline JWY1460 & 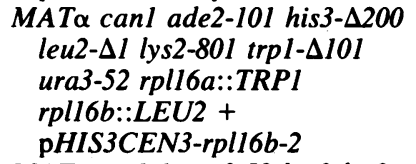 & This study \\
\hline JWY1446 & $\begin{array}{l}\text { MATa trpl-1 ura3-52 leu2 lys2- } \\
801 \text { his3- } 200 \text { rpll6a::TRP1 } \\
\text { RPL16B }\end{array}$ & This study \\
\hline JWY1448 & $\begin{array}{l}\text { MATa trp1-1 ura3-52 leu2 lys2- } \\
801 \text { his3- } 200 \text { rpll6a::TRP1 } \\
\text { rpll6b-2 }\end{array}$ & This study \\
\hline JWY1449 & $\begin{array}{l}\text { MATa trpl-1 ura3-52 leu2 lys2- } \\
801 \text { his3- } 2200 \text { rpll6a::TRPI } \\
\text { rpll6b-3 }\end{array}$ & This study \\
\hline DBY1828 & $\begin{array}{l}\text { MATa ade2 his } 3-\Delta 200 \text { leu2- } \\
3,112 \text { trpl-1 ura3-52 }\end{array}$ & D. Botstein \\
\hline DBY1829 & $\begin{array}{l}\text { MAT } \alpha \text { his } 3-\Delta 200 \text { leu2-3,112 } \\
\text { lys2-801 trpl-1 ura3-52 }\end{array}$ & D. Botstein \\
\hline
\end{tabular}

to transform JWY1402, which had been transformed with pHIS3CEN3-RPL16B to increase sporulation efficiency. $\mathrm{Ura}^{+}$transformants bearing a single copy of YIp5-rpll6b-2 or YIp5-rpll6b-3 integrated at the rpll6b::LEU2 locus were identified by Southern blotting (data not shown). Such transformants were induced to sporulate, and spore clones that had inherited the rpll6b::LEU2-YIp5-rpll6b-2 (or $-r p l 16 b-3)$ and $r p l 16 a:: T R P 1$ alleles were recovered among the progeny. These spore clones were grown nonselectively on YEPD (1\% yeast extract, $2 \%$ peptone, $2 \%$ dextrose), and then colonies that had lost $r p l 16 b:$ :LEU2-YIp5 were selected by replica plating to synthetic medium supplemented with 5-FOA. Southern blotting was used to ensure that these 
isolates bore the proper genomic configuration (data not shown). It was also verified that the isolates remained $\mathrm{Ts}^{-}$. The resulting strains were backcrossed twice to wild-type strain DBY1828 or DBY1829, depending on mating type, to confirm that they contain a single mutation conferring temperature sensitivity. JWY1446 was isolated in parallel from the backcrosses for use as a wild-type (with respect to $R P L 16 B$ ) control in subsequent experiments.

Yeast strains were grown in YEPD or in synthetic-complete medium lacking appropriate supplements (56) or supplemented with 5-FOA (5), depending on the experiment. Bacterial strains were grown in $\mathrm{LB}(0.5 \% \mathrm{NaCl}, 0.5 \%$ yeast extract, $1 \%$ tryptone) supplemented with $100 \mu \mathrm{g}$ of ampicillin per $\mathrm{ml}$, or in M9 medium lacking histidine (11).

Premixed YEPD and LB were purchased from GIBCO Laboratories (Madison, Wis.). Yeast extract, peptone, dextrose, and tryptone were purchased from Difco Laboratories (Detroit, Mich.). All restriction enzymes, linkers, and T4 DNA ligase were purchased from Boehringer Mannheim Biochemicals (Indianapolis, Ind.).

Plasmid-shuffling mutagenesis and DNA sequencing. Mutagenesis of $\mathrm{pHIS} 3 C E N 3-R P L 16 B$ was performed in vitro using hydroxylamine exactly as described previously (51). The extent of mutagenesis was determined to be $\sim 5 \%$ by transforming $E$. coli $\mathrm{HisB}$ to $\mathrm{Amp}^{\mathrm{r}}$ with mutagenized pHIS3CEN3-RPL16B and then counting the number of $\mathrm{Amp}^{\mathrm{r}} \mathrm{His}^{-}$transformants after replica plating to $\mathrm{M} 9$ medium lacking histidine (the yeast gene, HIS3, can complement the bacterial his $B 463$ mutant allele).

Plasmid shuffling (5) was employed to isolate mutations in $R P L 16 B$ as follows (see Fig. 1). JWY1457 was transformed with mutagenized pHIS3CEN3-RPLI6B. Approximately $20,000 \mathrm{His}^{+}$transformants were replica plated to synthetic medium supplemented with 5-FOA to isolate colonies that had lost the YCp50-RPL16B helper plasmid. The resulting $\mathrm{His}^{+} \mathrm{Ura}^{-}$colonies were replica plated to YEPD plates and incubated at 13,23 , and $37^{\circ} \mathrm{C}$. DNA was isolated (28) from the 80 transformants that grew at $23^{\circ} \mathrm{C}$ but not from those that grew at 13 or $37^{\circ} \mathrm{C}$, and it was used to transform $E$. coli. The potentially mutant $\mathrm{pHIS3CEN3-RPL16B}$ plasmids were then recovered from $E$. coli and shuttled back into JWY1457 by transformation. As before, YCp50-RPL16B was lost and the resulting $\mathrm{His}^{+} \mathrm{Ura}^{-}$strains were tested for growth at 13,23 , and $37^{\circ} \mathrm{C}$. Six isolates carried plasmids that conferred heat or cold sensitivity before and after plasmid shuffling.

A region in each of the six plasmids encompassing the entire RPL16B ORF and about 375 bp upstream was sequenced by using a double-stranded method (33), a Sequenase kit (United States Biochemicals, Cleveland, Ohio) and oligonucleotides complementary to the RPL16B ORF as primers. One strand of each RPL16B ORF was sequenced. Mutant alleles were subcloned into YIp5 and integrated into the genome as described in the previous section.

Polyribosome and ribosomal subunit characterization. Polyribosomes were extracted from cells lysed with glass beads and separated on 7 to $47 \%$ sucrose gradients as described previously (3). To cause polysomes to dissociate into ribosomal subunits and to separate the subunits on gradients, cultures were treated with $1 \mathrm{mM} \mathrm{NaN}_{3}$ for $15 \mathrm{~min}$ prior to harvesting, and cycloheximide and heparin were omitted from buffers. Ribosomal subunits were then separated on high salt $(0.5 \mathrm{M} \mathrm{KCl}), 7$ to $47 \%$ sucrose velocity gradients, at $27,000 \mathrm{rpm}$, in an $\mathrm{SW} 28$ rotor for $5 \mathrm{~h}$ at $13^{\circ} \mathrm{C}$ (69).

Growth curves and viability tests. Duplicate cultures of wild-type and mutant strains were grown overnight in YEPD at 23 or $30^{\circ} \mathrm{C}$, for heat- and cold-sensitive mutants, respectively, to a density of $\sim 10^{7}$ cells per $\mathrm{ml}$. One culture of each type was then shifted to the nonpermissive temperature (13 or $37^{\circ} \mathrm{C}$ ), and the remaining cultures were maintained at the permissive temperature. The $A_{610}$ of the four cultures was measured periodically. Viability of the cells was determined by removing samples from the cultures and spread plating approximately 100 cells (as determined by counting on a hemacytometer) on YEPD plates. Duplicate plates were incubated at permissive and nonpermissive temperatures, the latter to ensure that no revertants had arisen in the mutant cultures. To estimate viability after shifting to the nonpermissive temperature, the numbers of colonies that grew on plates spread with cells from the shifted versus the unshifted cultures were compared.

Analysis of rRNA synthesis. Our protocol for labeling and harvesting rRNA has been described previously $(29,41)$. RNA species were separated on $1.5 \%$ agarose- $6 \%$ formaldehyde gels in $1 \times$ MOPS buffer $(20 \mathrm{mM}$ MOPS [morpholinepropanesulfonic acid], $5 \mathrm{mM}$ sodium acetate, $0.8 \mathrm{mM}$ EDTA, 0.1\% diethyl pyrocarbonate) for $360 \mathrm{~V} \cdot \mathrm{h}$. After electrophoresis, RNA was nicked by soaking the gel in 75 $\mathrm{mM} \mathrm{NaOH}$ for $20 \mathrm{~min}$; the gel was then washed twice for 20 $\min$ in $0.5 \mathrm{M}$ Tris- $\mathrm{Cl}, \mathrm{pH} 7.4-1.5 \mathrm{M} \mathrm{NaCl}$ and then once in 25 $\mathrm{mM} \mathrm{Na} \mathrm{HPO}_{4}-\mathrm{NaH}_{2} \mathrm{PO}_{4}, \mathrm{pH} 6.5$ (38). RNA was transferred from the gel to Nylon 66 Plus membrane (Hoefer Scientific Instruments, San Francisco, Calif.) in $25 \mathrm{mM} \mathrm{Na}_{2} \mathrm{HPO}_{4}^{-}$ $\mathrm{NaH}_{2} \mathrm{PO}_{4}$, pH 6.5. The membrane was sprayed with En ${ }^{3}$ Hance (NEN Research Products, Wilmington, Del.) and placed under X-ray film.

Immunoblots of total protein and protein extracted from polyribosome gradients. Total protein was prepared from mid-logarithmic-phase cells by glass bead lysis in $100 \mathrm{mM}$ Tris, pH 8-20\% glycerol-1 mM dithiothreitol-1 mM phenylmethylsulfonyl fluoride. Samples were spun in a Microfuge for $1 \mathrm{~min}$. The supernatant was diluted in $1 \times$ Laemmli buffer (35) and loaded directly onto $17 \%$ polyacrylamide gels or stored at $-20^{\circ} \mathrm{C}$.

Protein was precipitated from polyribosome gradient fractions with $15 \%$ trichloroacetic acid on ice for $30 \mathrm{~min}$. The fractions were spun for $10 \mathrm{~min}$ in a Microfuge, washed with $5 \%$ trichloroacetic acid followed by an acetone wash, dried, and suspended in 1× Laemmli buffer. After polyacrylamide gel electrophoresis, proteins were electrophoretically transferred to nitrocellulose (Schleicher \& Schuell, Inc., Keene, N.H.) and immunoblots were made by using the Protoblot Immunoscreening System (Promega, Madison, Wis.) and anti-L16 antiserum (a gift of Y.-F. Tsay) at a dilution of $1: 200$.

Computer-aided homology and RNA secondary structure searches. The homologies shown in Fig. 2 were determined by using the computer programs FastA and TFastA, which are part of the University of Wisconsin Biotechnology Center's Genetics Computer Group's Sequence Analysis Software Package (12). These programs utilize the Pearson and Lipman method of searching for similarities (48). The GenBank, NBRF, EMBL, and Swiss-Prot data bases were searched. Thermodynamically favorable secondary structures were determined by using the StemLoop program, which is also a part of this software package. We accessed this software through the courtesy of the Pittsburgh Supercomputing Center. 

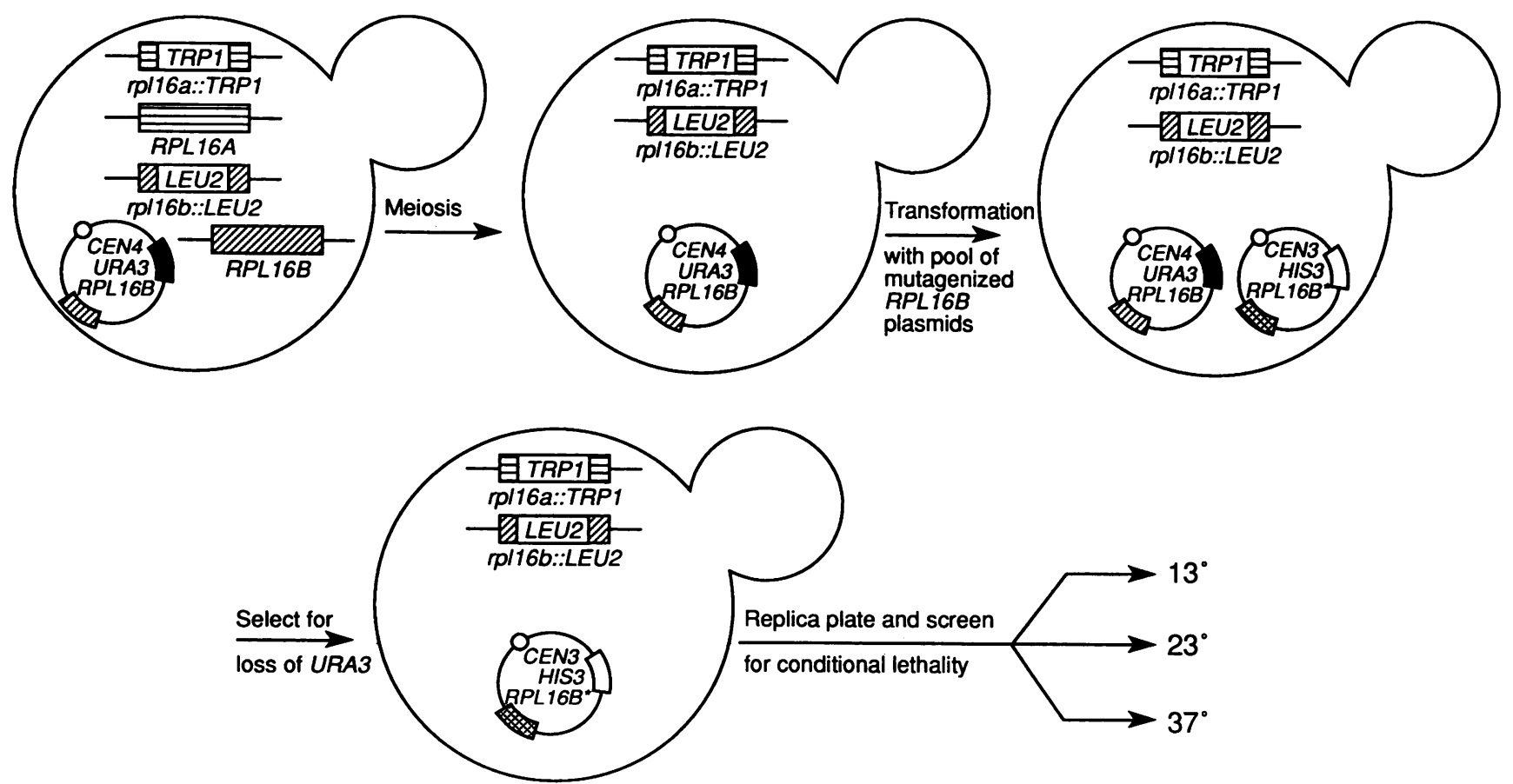

FIG. 1. Plasmid-shuffling mutagenesis scheme employed to isolate temperature-sensitive mutants defective for L16. Diploid JWY1402 (top, left) was transformed with YCp50-RPL16B and induced to undergo meiosis. Among the progeny, haploid JWY1457 (top, middle) was recovered. JWY1457 was transformed with a pool of hydroxylamine-mutagenized pHIS3CEN3-RPL16B plasmids. Transformants that had lost YCp50-RPL16B (wild type) were selected by replica plating to a 5-FOA-containing medium (bottom). The resulting Ura ${ }^{-} \mathrm{His}^{+}$isolates $^{-}$ were tested for conditional lethality at 13,23 , and $37^{\circ} \mathrm{C}$. Plasmids ( $\left.\mathrm{pHIS} 3 C E N 3-R P L 16 B\right)$ that putatively contained mutations conferring temperature sensitivity were isolated and retested by transforming JWY1457 and following through with the plasmid-shuffling scheme a second time.

\section{RESULTS}

Isolation of $r p l 16 b$ mutants. Temperature-sensitive mutants defective in r-protein L16 were sought by using the plasmidshuffling scheme (5) diagrammed in Fig. 1. A pool of pHIS3CEN3-RPLI6B plasmids was mutagenized in vitro with hydroxylamine (51), and strain JWY1457 was transformed with the mutagenized plasmids. Transformants that had lost the helper plasmid, YCp50-RPL16B, were selected on 5-FOA-containing medium (5). The resulting colonies were screened for temperature sensitivity at 37 and $13^{\circ} \mathrm{C}$. Potential mutants were confirmed by recovering $\mathrm{pHIS3}$ CEN3-RPL16B plasmids in E. coli, retransforming JWY1457 with the recovered plasmids, and testing the transformants again for temperature sensitivity. Six isolates continued to confer temperature sensitivity after plasmid shuffling. All six mutants were complemented by the wild-type $R P L 16 B$ allele on YCp50, demonstrating that temperature sensitivity was conferred by the RPLI6B-containing portion of the plasmid and that the mutant alleles are recessive. Mutations were identified by sequencing the ORFs and promoter regions of the six mutant alleles. These alleles are designated $r p l 16 b-1$ through rpll6b-6.

All of the mutants, except the one containing the rpll6b-4 allele, displayed a leaky temperature-sensitive phenotype; i.e., they were able to grow very slowly at the nonpermissive temperature. Because this might have been due to variation in the copy number of the pHIS3CEN3-rpll6b plasmid in the mutant strains, we tried to strengthen the phenotypes by placing the mutant alleles into the RPL16B locus in the genome. Phenotypes conferred by the rpll6b-2 and rpll6b-3 alleles were indeed tighter when these mutations were present at the genomic, rpll6b locus. However, the $r p l 16 b-1$ and rpll6b-6 alleles did not confer a stronger phenotype upon integration. Strains containing an integrated copy of $r p l 16 b-4$ or $r p l 16 b-5$ could not be constructed. The $r p l 16 b-5$ and $r p l 16 b-6$ alleles were not studied. Phenotypes conferred by rpll6b-1 or rpll6b-4 were studied in the strains originally isolated, JWY1459 or JWY1454, which contain plasmidborne mutant alleles.

rpll6b mutations and comparison to homologous proteins. The inferred protein sequence of L16 and the amino acid changes predicted by the mutations found in the six alleles are shown in Fig. 2. L16 homologs from other organisms are shown as well. The conserved region of these proteins is mainly confined to the middle, with the $\mathrm{N}$ and $\mathrm{C}$ termini being more divergent. Most of the mutations fall within the conserved domain of the protein. However, note that none of the mutations change residues that are invariant among all of the proteins. The rpll6b-2 and rpllob-3 alleles share one mutation, but rpll6b-2 has one additional mutation. We have not separated the mutations in rpll6b-2 to determine whether one or both of its mutations contribute to the phenotype. The rpll6b-4 allele also has two mutations, and these have not been separated either.

The rpll6b-1 allele confers both heat and cold sensitivity. Strains with the rpll6b-2, $-3,-5$, and -6 alleles are heat sensitive only. Strains bearing the rpll6b-4 allele are cold sensitive.

$r p l 16 b$ mutants recover after incubation at the nonpermissive temperature. Growth tests in liquid medium showed that strains JWY1448, 1449, and 1454, bearing rpll6b-2, rpll6b-3, and $r p l 16 b-4$, respectively, underwent at least several dou- 


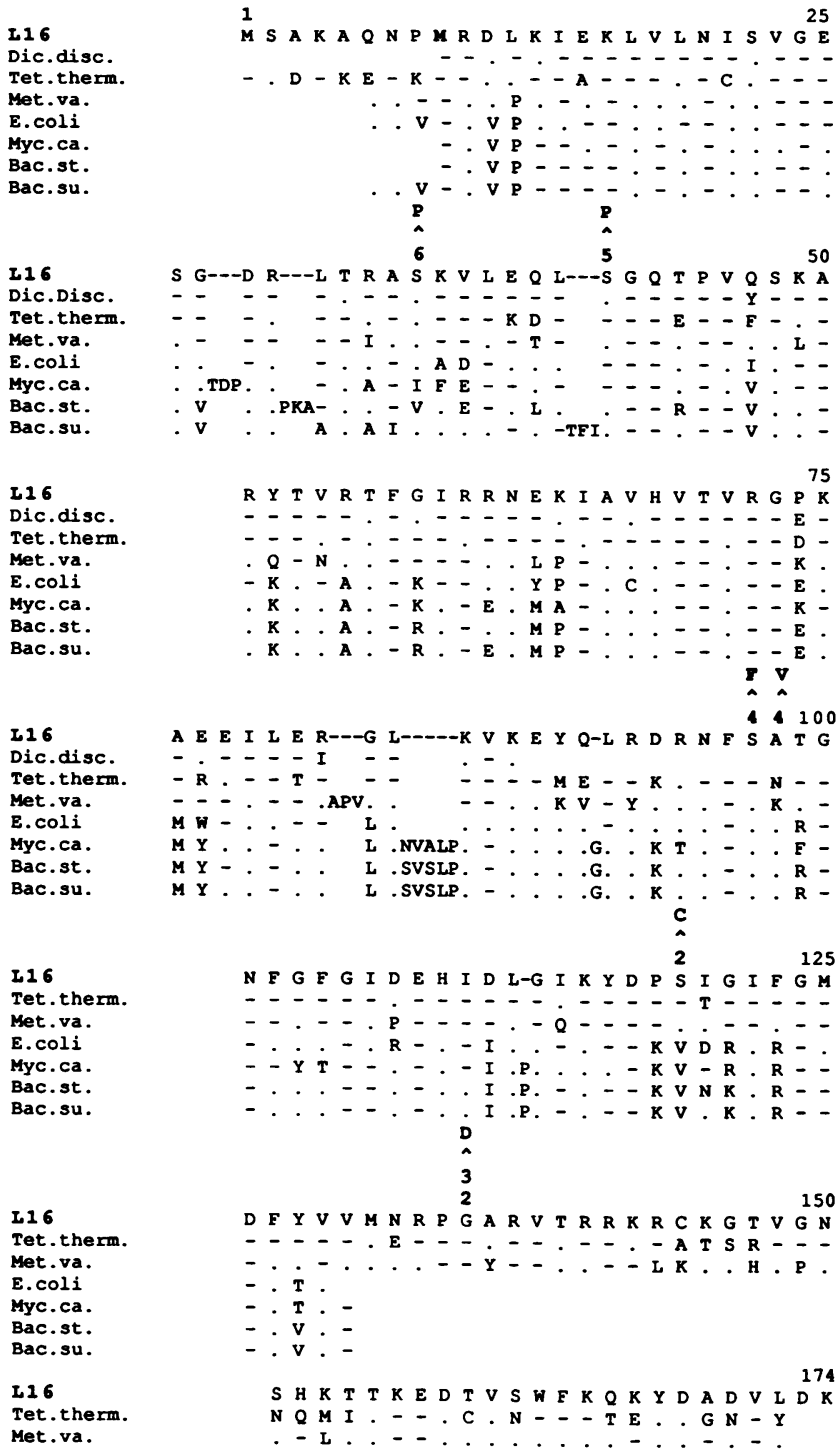

FIG. 2. Inferred L16 protein sequence and amino acid changes predicted to exist in the $r p l l 6 b-1$ through $r p l l 6 b-6$ alleles based on nucleotide changes. Above each predicted amino acid change is shown the mutant rpll6b allele number (1 to 6) and the predicted substitution (e.g., the nucleotide sequence of rpll6b-6 predicts a change from Ser to Pro at position 34 and is indicated as $6>\mathrm{P}$ ). Alleles rpll6b-2 and rpll6b-4 each contain two mutations. Allele $r p l l 6 b-l$ contains a mutation in the translation initiation codon. The next AUG codon, and presumed major translation start site for the $r p l 16 b-1$ allele, is eight codons downstream in the nucleotide sequence. The Met presumed to be the first amino acid residue in the mutant form of L16 is shown in bold (position 9). Comparisons to homologous proteins from other organisms are shown beneath the L16 sequence. The $\mathbf{N}$ termini of the bacterial homologs extend from 3 to 18 amino acid residues beyond that of L16 (not shown). Bacterial proteins also contain divergent $\mathrm{C}$ termini. Hyphens indicate amino acid identities among homologous proteins; periods indicate conservative changes. Abbreviations and protein names of L16 homologs: Dic.disc., Dictyostelium discoideum, V18 (59); Tet. therm., Tetrahymena thermophila, TL21 (34); Met.va., Methanococcus vannielii, L5 (2); E.coli, Escherichia coli, L5 (8); Myc.ca., Mycoplasma capricolum, L5 (47); Bac.st., Bacillus stearothermophilus, L5 (30); Bac.su., Bacillus subtilis, L5 (26). blings at their nonpermissive temperatures, although after the first doubling, they grew more slowly than strains that are wild type with respect to RPL16B (JWY1446 or JWY1458) (Fig. 3). The growth of JWY1459 (rpll6b-1) was almost indistinguishable from that of the wild-type strain JWY1458 at $13^{\circ} \mathrm{C}$. Growth of the rpll6b-3 strain at $37^{\circ} \mathrm{C}$ appeared to be similar to that of the wild type (Fig. 3D), but cell counts showed that this mutant was in fact growth impaired (data not shown). Presumably the misleading $\boldsymbol{A}_{610}$ values resulted from the aberrant cell shape and size associated with this mutation (see below).

Strains 1459 and 1454 (rpll6b-1 and rpll6b-4) also grew less well than the wild type at the permissive temperature (Fig. 3A). The growth rates of strains 1448 and 1449 (rpll6b-2 and $r p l l 6 b-3)$ were approximately the same as that of the wild type at the permissive temperature (Fig. 3C).

The mutant cells displayed aberrant morphologies at nonpermissive temperatures. Within $2 \mathrm{~h}$ after JWY1448 $(r p l 16 b-2)$ and JWY1449 (rpll6b-3) were shifted to $37^{\circ} \mathrm{C}$, the cells appeared to be much larger and often had multiple and misshapen buds. These phenotypes became more pronounced with time at the nonpermissive temperature. JWY1459 (rpll6b-I) cells appeared large and misshapen and had multiple buds at both 13 and $30^{\circ} \mathrm{C}$. Curiously, most JWY1454 (rpll6b-4) cells did not exhibit these morphological phenotypes, even though the only known difference in genotype is the rpll6b allele.

Viability of the mutant strains was tested by periodically spread plating cells from all cultures used to determine growth curves. Duplicate plates from each culture and time point were incubated at permissive and restrictive temperatures. Colonies did form from cells incubated at the nonpermissive temperature in liquid and plated at the permissive temperature on solid medium. However, except for JWY $1459(r p l l 6 b-1)$, the mutants were unable to form colonies on plates incubated at the nonpermissive temperature. JWY 1459 cells formed small colonies after 2 weeks at $13^{\circ} \mathrm{C}$. We did note an approximate $40 \%$ loss of viability for strain JWY $1454\left(\right.$ rpll6b-4) after it had been maintained at $13^{\circ} \mathrm{C}$ for greater than $24 \mathrm{~h}$.

rpl16b mutants accumulate fewer $60 S$ subunits at the nonpermissive temperature. The effects of rpll6b mutations on ribosome assembly and function were determined by extracting polyribosomes from the cells and separating them on sucrose gradients. The rpll $6 b$ mutants accumulate fewer free $60 \mathrm{~S}$ subunits in proportion to $40 \mathrm{~S}$ subunits at the nonpermissive temperature than do wild-type cells (Fig. 4). The rpll6b-1 mutant displays the least severe deficit of $60 \mathrm{~S}$ subunits (Fig. 4B). This is consistent with the facts that it contains some wild-type L16 protein (see below) and that it grows better at its restrictive temperature than do the other mutants (Fig. 3). Each of the mutants has a measurable but less severe deficit of $60 \mathrm{~S}$ subunits at the permissive temperature (data not shown).

Because of the shortage of $60 \mathrm{~S}$ subunits, half-mer polyribosomes accumulate (Fig. 4C, E, and F). These represent $43 \mathrm{~S}$ to $48 \mathrm{~S}$ translational preinitiation complexes $(25,52)$. Although not evident here (Fig. 4B), half-mers are sometimes discernible in polyribosome profiles of the rpllob-l mutant. In addition, in the mutants, mRNA species are associated with fewer ribosomes than is the case in wild-type strains (compare polyribosome peaks of mutant and wildtype strains). The simplest explanation is that this is an indirect effect of the $60 \mathrm{~S}$ subunit deficit rather than a reflection of altered $60 \mathrm{~S}$ function. These phenotypes are characteristic of all rpll6 mutants studied to date $(41,52)$. 
A.

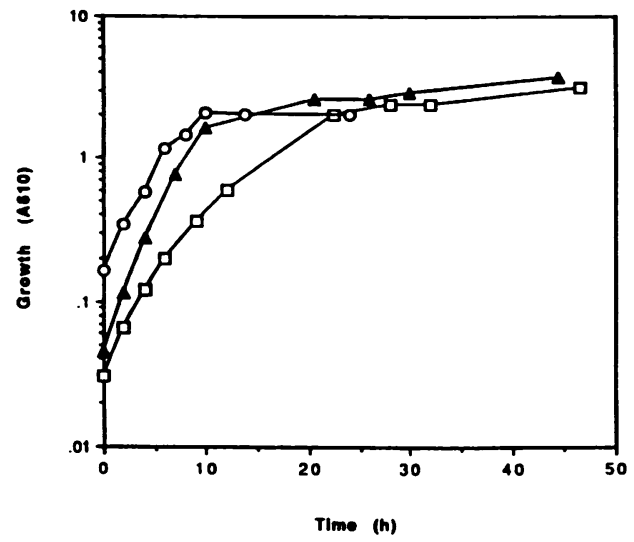

c.

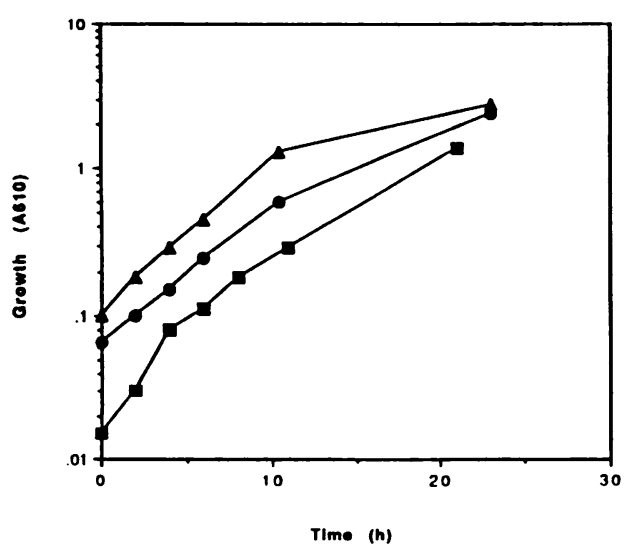

B.
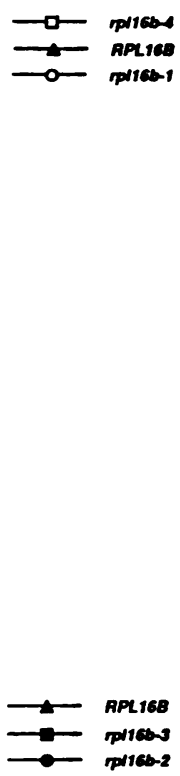

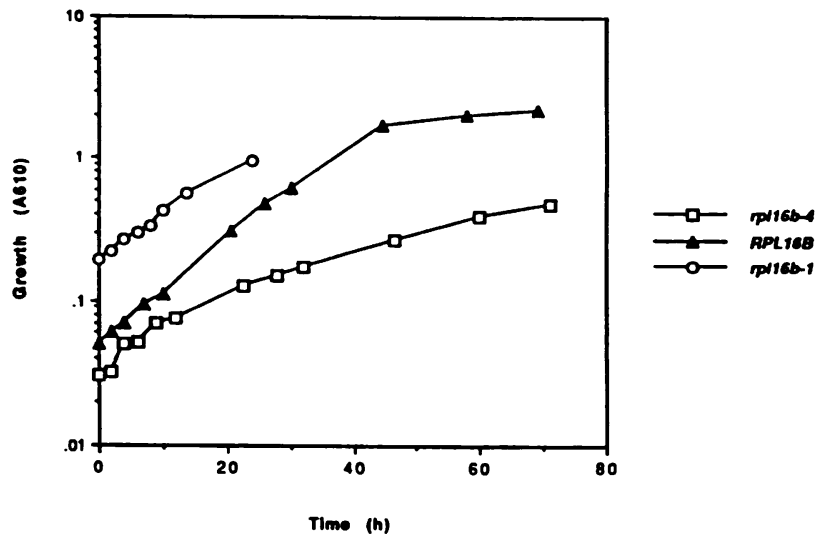

D.

$37^{\circ} \mathrm{C}$

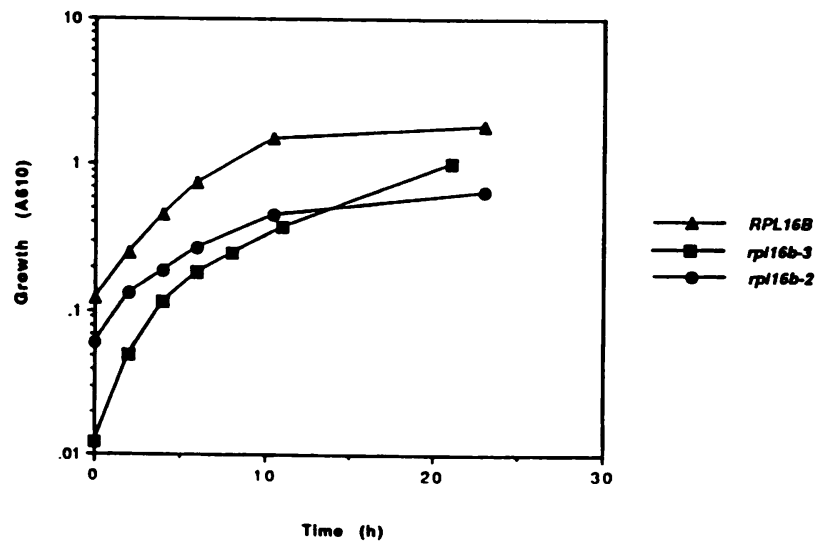

FIG. 3. Growth curves of $r p l 16 b$ mutants. At $0 \mathrm{~h}$, cultures grown in YEPD at the permissive temperature $\left(23\right.$ or $30^{\circ} \mathrm{C}$, depending on the mutant) overnight were either maintained at the permissive temperature or shifted to the restrictive temperature $\left(13\right.$ or $\left.37^{\circ} \mathrm{C}\right)$. The $A_{610}$ of the cultures was monitored periodically over the time courses shown on each graph. Strains used in this experiment: (A and B) JWY1454, JWY1458, and JWY1459; (C and D) JWY1446, JWY1448, and JWY1449.

$r p l 16 b$ mutants are deficient in mature $25 S$ rRNA and the $r$ ll $6 b-4$ mutant accumulates rRNA precursors. We examined the synthesis and accumulation of rRNAs in the temperature-sensitive mutants grown at the permissive temperature or shifted to the restrictive temperature by performing pulse-chase experiments. In wild-type cells, the mature $25 \mathrm{~S}$, $5.8 \mathrm{~S}$, and $18 \mathrm{~S}$ rRNAs are derived through several processing steps from a $35 \mathrm{~S}$ rRNA precursor (diagrammed in Fig. 5A). The 5S rRNA is synthesized as a separate transcript (66).

All of the mutants failed to accumulate wild-type levels of mature 25S rRNA, as compared with $18 \mathrm{~S}$ rRNA, at the nonpermissive temperature, but at the permissive temperature 25S accumulation was nearly normal (Fig. 5). Mutant JWY1454 (rpll6b-4) processed rRNA precursors more slowly than did wild-type strains, as evidenced by the accumulation of $35 \mathrm{~S}, 32 \mathrm{~S}$, and $27 \mathrm{~S}$ rRNAs. At the nonpermissive temperature, $35 \mathrm{~S}, 32 \mathrm{~S}$, and $27 \mathrm{~S}$ precursors were evident in the rpll6b-4 strain even during the chase (Fig. 5D). At $13^{\circ} \mathrm{C}$, wild-type strain JWY 1458 showed some accumulation of $35 \mathrm{~S}, 32 \mathrm{~S}$, and $27 \mathrm{~S}$ precursors during the chase, but not to the extent seen for JWY1454 (rpll6b-4; Fig. 5D). Note also the novel bands that migrate between $25 \mathrm{~S}$ and $20 \mathrm{~S}$
rRNAs in samples from JWY 1454 at $13^{\circ} \mathrm{C}$. We have not determined the identity or origin of these novel RNAs.

rRNA synthesis and accumulation in JWY1459 (rpll6b-l) was not characterized. This experiment awaits construction of a site-directed mutation that results in the synthesis of only the smaller form of L16 seen in JWY1459 (see below).

rpl16b-1 encodes two forms of L16 that are both assembled into functional $60 \mathrm{~S}$ subunits. The mutation in the rpll6b-1 allele lies in the translation initiation codon, which is converted from AUG to AUA (data not shown), suggesting that this allele would encode a smaller form of L16 (Fig. 2). In the wild-type allele, as well as in the rpllob-1 allele, the next AUG lies at the ninth codon downstream. Because eukaryotic ribosomes, including those of $S$. cerevisiae, normally initiate translation at the first AUG encountered on an mRNA $(9,31,57)$, the $r p l 16 b-1$ allele would be expected to encode a form of L16 lacking the first eight amino acid residues. This possibility was tested by immunoblotting of total protein extracted from mutant JWY1459. Surprisingly, two forms of L16 were detected in this strain: one of wild-type size and low abundance and the expected smaller form, which was approximately as abundant as L16 is in 

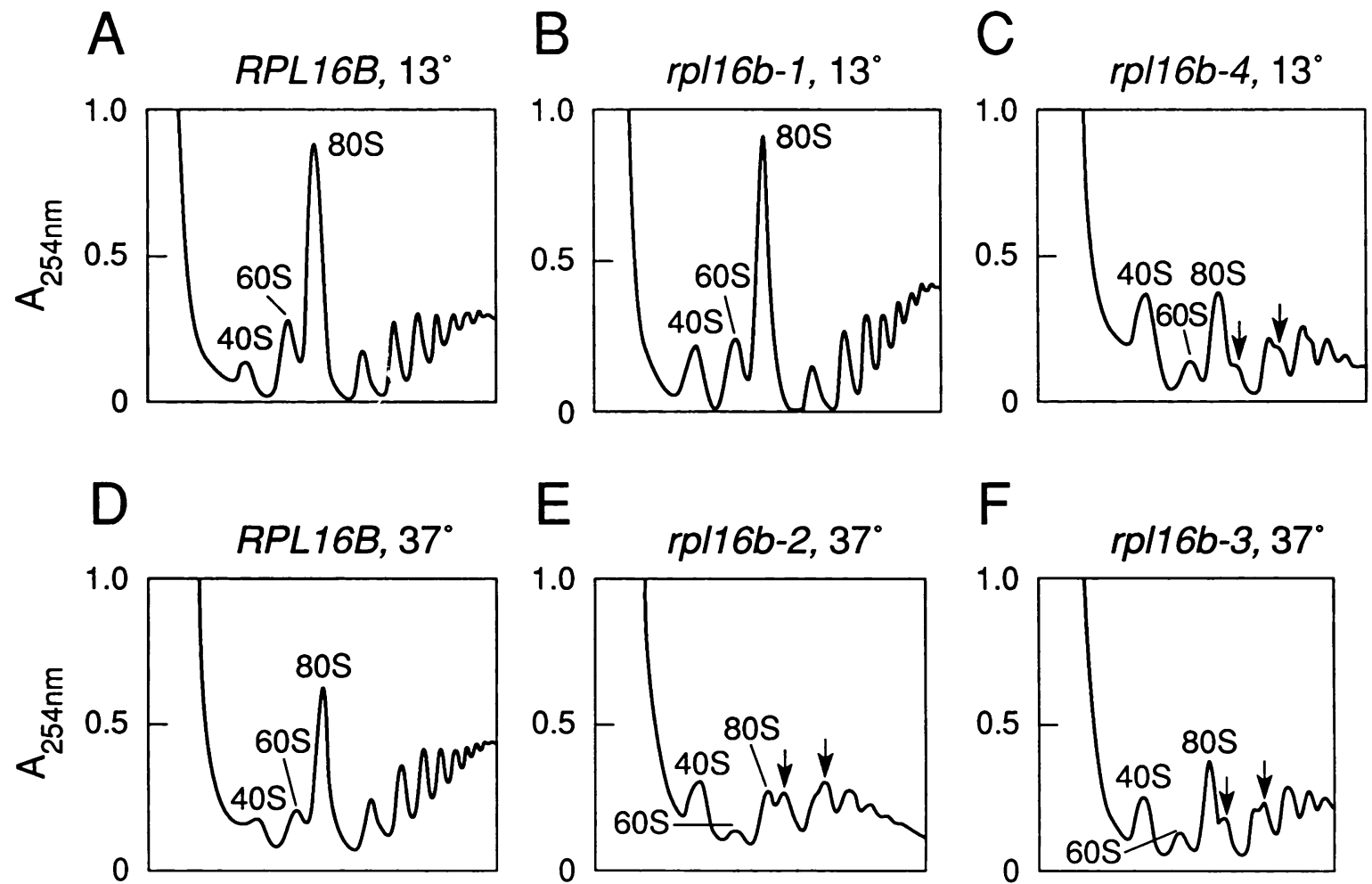

FIG. 4. Polyribosome profiles of the rpll6b mutants after shifting to the restrictive temperature for $2 \mathrm{~h}$. Free ribosomal subunits and polyribosomes in cell lysates were separated on 7 to $47 \%$ sucrose velocity gradients. Peaks representing free $40 \mathrm{~S}$ and $60 \mathrm{~S}$ subunits and $80 \mathrm{~S}$ monoribosomes are labeled. Peaks representing half-mer polyribosomes are marked with arrows. Strains used in this experiment: (A) JWY1458, (B) JWY1459, (C) JWY1454, (D) JWY1446, (E) JWY1448, (F) JWY1449.

wild-type strain JWY1458 (Fig. 6A). Thus, ribosomes in JWY1454 are able to initiate translation at the AUA in rpll6b-l at an appreciable frequency.

The fact that $r p l 16 b-1$ cells growing well at the permissive temperature contain mostly the short form of L16 indicates that this form can assemble into functional $60 \mathrm{~S}$ subunits. This was confirmed by immunoblot assays of ribosomal subunits and polyribosomes isolated from JWY1456 grown at the permissive temperature. Both forms of L16 were found in fractions containing $60 \mathrm{~S}$ subunits, $80 \mathrm{~S}$ monoribosomes, and polyribosomes (data not shown). It is unlikely that this result was due to a nonspecific distribution of the mutant form of L16 across the gradient or comigration of nascent mutant protein with polyribosomes because neither form of L16 was associated with fractions containing free $40 \mathrm{~S}$ subunits (data not shown). However, to confirm that both forms of L16 were tightly associated, integral components of $60 \mathrm{~S}$ subunits, ribosomes were extracted again from JWY1459 and exposed to azide and high salt to cause polysome runoff and subunit dissociation. The subunits were separated on high-salt gradients, protein was precipitated from gradient fractions, and immunoblotting was performed. Both forms of L16 were associated with fractions containing $60 \mathrm{~S}$ subunits and absent from fractions containing $40 \mathrm{~S}$ subunits (Fig. 6B).

Similar experiments were performed with rpllob-l cells that had been shifted to $13^{\circ} \mathrm{C}$ to determine whether there were any differences in distribution of the small, mutant protein across the polysome or subunit gradients. No differences were detected (data not shown). The presence of mutant $60 \mathrm{~S}$ subunits in polysome fractions at the nonpermis- sive temperature suggests that these subunits are functional in translation at $13^{\circ} \mathrm{C}$. However, such experiments do not differentiate between ribosomes synthesized before the shift from those synthesized after. Thus, without further experiments, we cannot conclude whether mutant $60 \mathrm{~S}$ subunits assemble at $13^{\circ} \mathrm{C}$ in JWY1459.

\section{DISCUSSION}

Temperature-sensitive mutants defective in r-protein L16 were isolated through hydroxylamine mutagenesis (51) of the $R P L 16 B$ gene and plasmid shuffling (5). Of approximately 20,000 transformants screened, six mutants were isolated, suggesting that this gene may not be particularly mutable to temperature sensitivity.

Given that L16 is a highly conserved r-protein, with homologs in eubacteria, archaebacteria, Tetrahymena spp., and Dictyostelium spp. (Fig. 2), it may be that there are only a few possible mutations in $R P L 16 B$ that are not unconditionally lethal. Alternatively, many different mutations in $R P L 16 B$ may be tolerated since ribosome assembly involves many molecules that might help a mutant form of L16 assume and maintain its position in the $60 \mathrm{~S}$ subunit. Once assembled, one mutant protein may not make a significant difference to the ultrastructure of the $60 \mathrm{~S}$ subunit, which contains approximately 50 different molecules. These possible explanations for the inability to isolate many mutants are testable by site-directed mutagenesis of invariantly conserved regions within $R P L 16 B$. The failure to isolate many mutants was somewhat unexpected, since temperature-sen- 
A
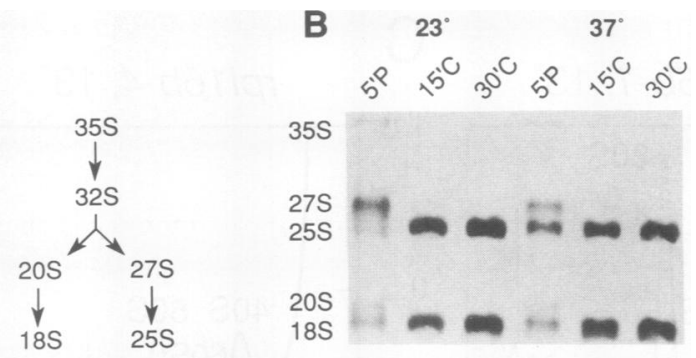

RPL16B

C
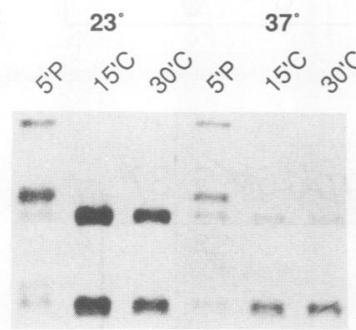

$r p / 16 b-2$

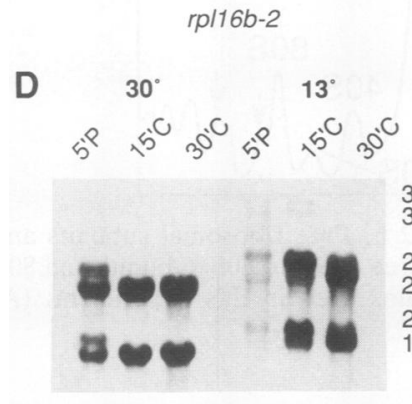

RPL16B

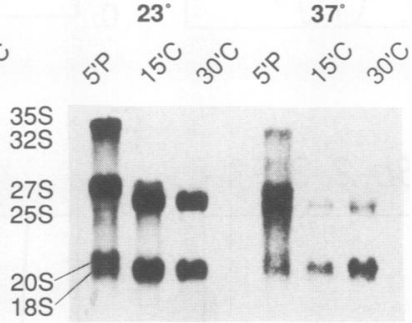

$r p / 16 b-3$

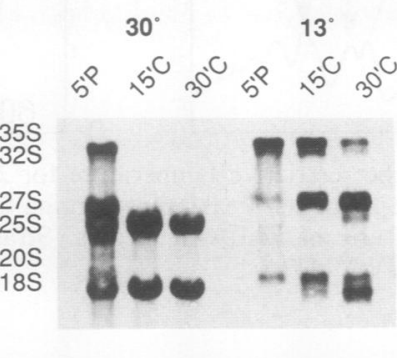

rp/16b-4
FIG. 5. Synthesis and accumulation of rRNA in rpll6b mutants. The cells were grown at the permissive temperature or shifted to the restrictive temperature for $2 \mathrm{~h}$. RNA samples were prepared from cells after pulse-labeling with L- $\left[\right.$ methyl $\left.-{ }^{3} \mathrm{H}\right]$ methionine for $5 \mathrm{~min}$, and after chasing the label for 15 and $30 \mathrm{~min}$ with unlabeled methionine. L- $\left[\right.$ methyl $\left.^{3} \mathrm{H}\right]$ methionine labels rRNA through the donation of ${ }^{3} \mathrm{H}$-methyl groups. Species of rRNA were resolved on $1.5 \%$ agarose gels, rRNA was transferred from gels to Nylon 66 Plus membrane, and the membrane was sprayed with $\mathrm{En}^{3} \mathrm{Hance}$ and exposed to X-ray film. Species of rRNA are labeled according to their sedimentation coefficients. (A) Simplified rRNA processing pathway. Strains used in this experiment: (B) JWY1446; (C) JWY1448 (left) and JWY1449 (right); (D) JWY1458 (left) and JWY1454 (right).

sitive (particularly cold-sensitive) ribosomal subunit assembly mutants have been isolated in $E$. coli $(6,21,62)$.

Both heat- and cold-sensitive mutants defective for L16 were isolated. The rpll6b-1 mutant allele confers both heat and cold sensitivity. The rpllibb-4 allele confers cold sensitivity. The other four mutants are heat sensitive. Growth curves (Fig. 3) and viability tests of JWY1448 (rpll6b-2), JWY1449 (rpll6b-3), and JWY1454 (rpll6b-4) show that the growth of these mutants at their nonpermissive temperatures is slow, but if returned to the permissive temperature after as much as $\mathbf{2 4} \mathrm{h}$, most of the cells are still viable and can form colonies slowly on plates. Growth of JWY1459 (rpllob-l) is less affected at the restrictive temperature, perhaps because JWY1459 contains some wild-type protein.

The ability of these mutants to undergo several doublings
A

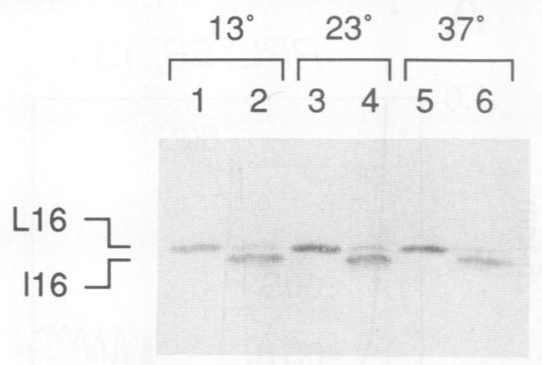

B

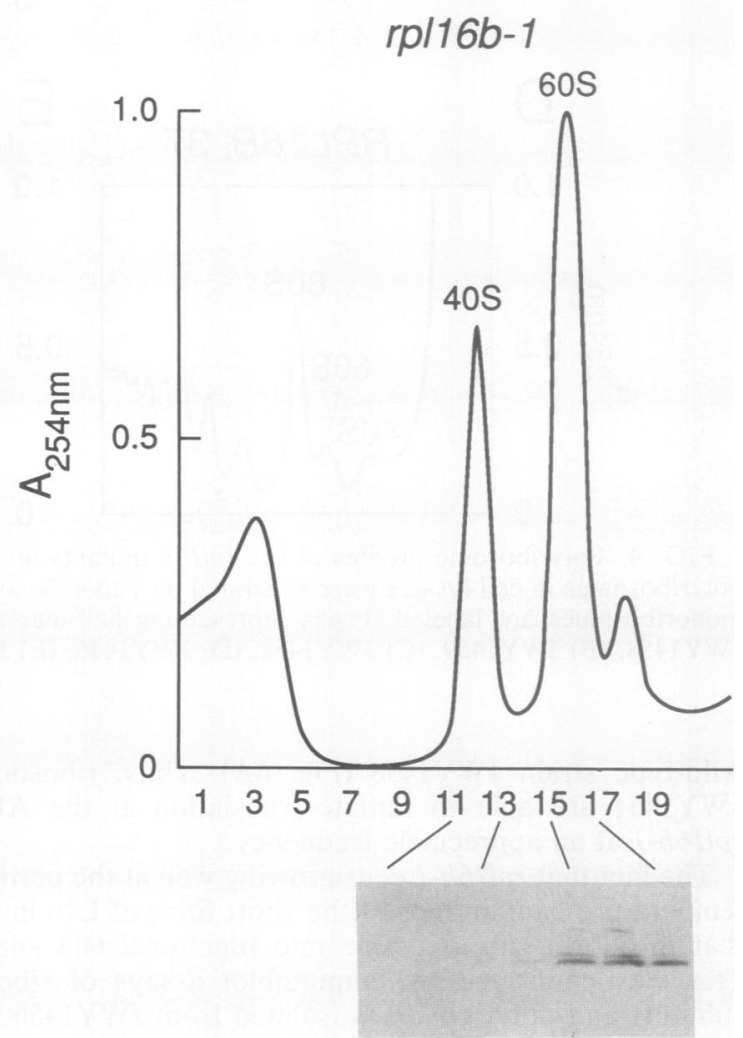

FIG. 6. The rpll6b-1 mutant synthesizes two forms of L16 that both assemble into $60 \mathrm{~S}$ subunits. (A) Total protein was extracted from wild-type JWY1458 (lanes 1, 3, and 5) and JWY1459 (rpll6b-1, lanes 2,4 , and 6). Cells were grown at $23^{\circ} \mathrm{C}$ or shifted to 13 or $37^{\circ} \mathrm{C}$ for $2 \mathrm{~h}$. Both 23 and $30^{\circ} \mathrm{C}$ are permissive for the rpllob-l strain. Protein was subjected to immunoblotting with anti-L16 antiserum. L16, wild-type size L16; 116, mutant L16 protein. (B) Ribosomal subunits prepared from $r p l 16 b-1$ cells grown at $23^{\circ} \mathrm{C}$ were separated by centrifugation on sucrose velocity gradients. Protein was precipitated from gradient fractions and subjected to immunoblotting with anti-L16 antiserum. The immunoblot is shown below the absorbance profile, and the fraction of origin for each protein sample is indicated. In lanes 15 to 17 , wild-type size L16 is represented by the faint upper band and the smaller, mutant L16 is represented by the lower band.

and to survive prolonged periods at the nonpermissive temperature may be general phenomena of ribosome assembly mutants. We have observed this phenotype previously in studies of mutants conditional for the synthesis of L16 or the 40S subunit protein, rp59 (41). Mutants conditional for synthesis of RNA polymerase I, which catalyzes the synthe- 
sis of the $35 \mathrm{~S}$ rRNA precursor, are also able to undergo several doublings in the absence of RNA polymerase I (73). Upon termination of synthesis of $\mathrm{U} 14$, a small nucleolar RNA involved in processing of $20 \mathrm{~S}$ pre-rRNA, cells are able to double several times as well. When these cells were returned to the permissive condition 4.5 or $12 \mathrm{~h}$ postshift, 80 to $90 \%$ were found to be viable (38). Growth of yeast cells depleted of Noplp (fibrillarin), a protein required for prerRNA processing, is not immediately inhibited either (63).

These phenotypes contrast those of many $\mathrm{Ts}^{-}$cell division cycle mutants, for instance, which die after prolonged periods at the nonpermissive temperature (24). Strains carrying mutations in the $P R T 1$ gene, which appears to encode a nonribosomal protein involved in translation initiation, arrest with a classical cell division cycle mutant phenotype at START $(16,22)$. START refers to the cell cycle regulatory step that occurs at $G_{1}$ in $S$. cerevisiae (50). The ability of $r p l 16 b$ mutants to survive and even divide at the restrictive temperature suggests that the mutant ribosomes assembled before the shift are not defective for function in translation. However, this must be tested directly.

Mutants JWY1448 (rpll6b-2), JWY1449 (rpll6b-3), and JWY1454 (rpll6b-4) all have a shortage of 60 S subunits and accumulate half-mer polyribosomes (Fig. 4). Strain JWY $1459(r p l 16 b-1)$ is again less severely affected. It is slightly deficient in 60S subunits, and half-mers are only apparent occasionally. Since these phenotypes are also characteristic of mutants known to have a deficit of $\operatorname{L16}(41,52)$, we determined the stability of the mutant forms of $\mathrm{L16}$ that were synthesized at the nonpermissive temperatures. Newly synthesized L16 appeared to be unstable in the mutants at the restrictive temperatures (data not shown).

The shortage of $60 \mathrm{~S}$ subunits and the instability of L16 in the mutants might have been due to abortive assembly of subunits or to instability of mature subunits. Since it is known that proper synthesis and processing of precursor rRNA depends on continued assembly of ribosomes $(66,67)$, we sought to distinguish between these possibilities by characterizing rRNA synthesis and processing in the mutants. If ribosome assembly were defective, one might expect it to be reflected in aberrant synthesis, accumulation, or processing of precursor rRNA. If ribosomes were assembled and then degraded because of a structural perturbation and subsequent instability caused by mutant $\mathrm{L16}$, synthesis and processing of pre-rRNA would probably be normal and only accumulation of mature rRNA would be affected.

None of the mutants tested (JWY1448 [rpll6b-2], JWY 1449 [rpll6b-3], and JWY1454 [rpll6b-4]) accumulated wildtype levels of $25 S$ rRNA (Fig. 5). In addition, JWY1454 $(r p l 16 b-4)$ clearly accumulated precursor rRNAs in excess of that found in wild-type strains. Thus, for the rpll6b-4 mutant, the defect appears to be at the level of $60 \mathrm{~S}$ subunit assembly rather than at the level of subunit stability. However, it is possible that both assembly and stability are affected. The data for JWY1448 (rpll6b-2) and 1449 $(r p l 16 b-3)$ suggest a slightly slowed processing of precursors (Fig. 5C, 5'P lanes), but the effects are too subtle to conclude that assembly is affected for these mutants.

Accumulation of pre-rRNAs in JWY1454 (rpll6b-4) suggests that ribosome assembly is slowed down in this mutant. We are hopeful that it will be possible to isolate precursor ribosomes from this strain and thereby begin to characterize the in vivo assembly pathway of a eukaryotic ribosome.

Accumulation of rRNA precursors has been observed in other mutants as well. Mutants defective for nuclear localization of r-protein L29 accumulate pre-rRNAs (67). Precur- sors accumulate in a cold-sensitive pseudorevertant of a pabl [poly(A) binding protein] mutant that contains a mutation in the SPB4 gene, which encodes a putative rRNA helicase (54). Both of these mutants also lack wild-type levels of $60 \mathrm{~S}$ subunits.

Mutant JWY1454 (rpll6b-4) contained two novel RNA species (Fig. 5), whose origin and identity remain to be determined. The larger of these two molecules appears to be about the same size as a novel RNA observed by $\mathrm{Li}$ et al. in the U14 mutant mentioned above (38). Whether these RNAs are the same will require further study.

Although it was not tested directly, we suspect that the mutant ribosomes in our strains are not defective for function because the mutants are able to survive, and even double several times, at the nonpermissive temperatures. In addition, we were able to label newly made protein with radioactive methionine after the mutants had been at the restrictive temperatures for $2 \mathrm{~h}$ in order to test stability of mutant forms of L16 (data not shown). This shows that the mutant ribosomes were functional at the nonpermissive temperature. The presence of the small form of L16 encoded by the rpll6b-1 allele in polysomes also demonstrates that $60 \mathrm{~S}$ subunits of this mutant are functional (data not shown). However, a slight impairment of function cannot be ruled out. In tests of the mutants for drug sensitivities we noted a slightly enhanced sensitivity of the rpllob-l and -4 mutants to cycloheximide, suggesting that these mutant $60 \mathrm{~S}$ subunits may be slightly impaired for function (data not shown).

The mutation in the rpll6b-l allele resides in the translation initiation codon (AUG to AUA), which suggested that a smaller form of L16 lacking the first eight amino acid residues would be synthesized in this strain. Immunoblots show that this mutant actually synthesizes two forms of L16, one of wild-type size which is of low abundance and one of the expected, smaller size which is of wild-type abundance (Fig. 6A). Both forms of L16 were found in $60 \mathrm{~S}$ subunits, and subunits containing the mutant form appear to be functional in translation at permissive and restrictive temperatures (Fig. 6B and data not shown).

It is interesting that the nonconserved $\mathrm{N}$-terminal extension of L16 is precisely what is missing from the mutant form of L16 encoded by the rpll6b-1 allele (Fig. 2). The relative health of the rpll6b-1 strain suggests that this part of L16 may not be very important for L16 function in S. cerevisiae, although this could also be due to the presence of some wild-type L16 in this strain.

Site-directed mutagenesis of the initiation codon of $R P L 16 B$ to replace it with a codon at which ribosomes will be less likely to initiate than they are at AUA should reveal the effects of the smaller form of L16 on ribosome assembly and function in the absence of wild-type L16.

The existence of two forms of L16 in JWY1459 is a surprising result, since eukaryotic ribosomes, including those of $S$. cerevisiae, normally initiate at the first AUG encountered on an mRNA $(9,31,57)$. However, yeast ribosomes have been observed previously to initiate translation at AUA at a very low frequency $(13,75)$. Donahue and Cigan did not find the extent of initiation at AUA to be physiologically relevant for the HIS4 gene; i.e., it could not confer a His ${ }^{+}$phenotype (13). Nor did Sherman and Stewart find initiation at AUA to result in sufficient synthesis of iso-1-cytochrome $c(57)$. We have not quantified the contribution of wild-type L16 in JWY1459, so we do not know whether the frequency of initiation at AUA in this strain exceeds that observed by other investigators.

An interesting possibility is that the ability of ribosomes to 
initiate at AUA in JWY1459 may be enhanced because of the shortage of $60 \mathrm{~S}$ subunits in this strain. The stalling of preinitiation complexes around the first AUG of mRNAs might increase the frequency of translation initiation at noncanonical codons. In support of this notion, M. Kozak has shown that a secondary structure downstream of GUGs, UUGs, or AUGs that are in a poor context facilitates the recognition of these codons by the ribosome as points for initiation in vitro (32). We believe that there must be an explanation other than a downstream secondary structure for the observed initiation at AUA in the rpll6b-l mRNA, because thermodynamically favorable downstream secondary structures are not predicted to exist by a computer-aided inspection of the RPLI6B sequence (data not shown).

The ability of the deficit of $60 \mathrm{~S}$ subunits in a haploid strain containing a null allele of $R P L 16 B$ to affect translation initiation has been observed by others. In an rpll6 $b$ null strain, GCN4, the transcriptional activator of amino acid biosynthetic genes, is derepressed under nonstarvation conditions. GCN4 expression is regulated at the translational level by amino acid availability. This mechanism involves four small ORFs that are present upstream of the GCN4 translation start site. Normally, under nonstarvation conditions, the upstream ORFs are translated and reinitiation of translation at the AUG of GCN4 is prevented. Under starvation conditions, the frequency of the reinitiation of translation increases and the GCN4 ORF is translated (reviewed in reference 27). However, in the rpll6b null strain, reinitiation at the GCN4 ORF is increased under nonstarvation conditions, presumably because of the shortage of $60 \mathrm{~S}$ subunits (18).

If initiation at AUA in the rpll6b-l mutant is due to the shortage of $60 \mathrm{~S}$ subunits, aberrations in translation initiation might be occurring on many different mRNAs in this strain, thereby resulting in the synthesis of a variety of altered proteins that may be toxic to the cells. Thus, the slow growth of the rpllob-1 mutant might be due to both the shortage of $60 \mathrm{~S}$ subunits and the synthesis of aberrant proteins. The possibility of proteins other than L16 being altered in this mutant might be testable by immunoblotting or by testing for specific phenotypes, such as auxotrophies or prototrophies, that only exist in the mutant background.

Since all of the rpll6b mutants isolated are deficient for $60 \mathrm{~S}$ subunits and accumulate half-mers, all of them should exhibit a higher frequency of initiation at codons other than AUG, according to our model. This possibility is testable. Finally, it is possible that the mutant $60 \mathrm{~S}$ subunits themselves somehow decrease the fidelity of translation initiation.

In conclusion, the phenotypes of the temperature-sensitive $r p l 16 b$ mutants described here suggest that the mutants are primarily defective for $60 \mathrm{~S}$ subunit assembly. However, the shortage of $60 \mathrm{~S}$ subunits in these strains may lead to an increased frequency of translation initiation at noncanonical codons. Thus, these mutants bring to light a possible connection between the rate and the fidelity of translation initiation. This connection has been suggested recently by M. Kozak as a result of in vitro experiments that are very different from those described here (32). Further experiments will be required to test this model for the mechanism by which ribosomes normally translate mRNA into protein with such fidelity.

\section{ACKNOWLEDGMENTS}

We thank Marco Foiani, Mark Cigan, Charlie Moehle, and Alan Hinnebusch (National Institutes of Health [NIH]) for fruitful discus- sions and communication of results prior to publication. We also thank Charlie Moehle for a critical reading of the manuscript.

This work was supported by U.S. Public Health Service grant GM-28301 from NIH. J. Woolford was supported by Research Career Development Award CA-01000 from the National Cancer Institute, M. Moritz was supported in part by an NIH National Research Service Award (GM08067) awarded to the Department of Biological Sciences, and B. Pulaski was a recipient of a National Science Foundation Research Experience for Undergraduates award (BBS8712919).

\section{REFERENCES}

1. Andrew, C., A. K. Hopper, and B. D. Hall. 1976. A yeast mutant defective in the processing of $27 \mathrm{~S}$ rRNA precursor. Mol. Gen. Genet. 144:29-37.

2. Auer, J., G. Spicker, and A. Boeck. 1989. Organization and structure of the Methanococcus transcriptional unit homologous to the Escherichia coli "spectinomycin operon." Implications for the evolutionary relationship of $70 \mathrm{~S}$ and $80 \mathrm{~S}$ ribosomes. J. Mol. Biol. 209:21-36.

3. Baim, S. B., D. F. Pietras, D. C. Eustice, and F. Sherman. 1985. A mutation allowing an mRNA secondary structure diminishes translation of Saccharomyces cerevisiae iso-1-cytochrome $c$. Mol. Cell. Biol. 5:1839-1846.

4. Bayliss, F. T., and J. L. Ingraham. 1974. Mutation in Saccharomyces cerevisiae conferring streptomycin and cold sensitivity by affecting ribosome formation and function. J. Bacteriol. 118:319-328.

5. Boeke, J. D., J. Trueheart, G. Natsoulis, and G. R. Fink. 1987. 5-Fluoroorotic acid as a selective agent in yeast molecular genetics. Methods Enzymol. 154:164-175.

6. Bryant, R. E., and P. S. Sypherd. 1974. Genetic analysis of cold-sensitive ribosome maturation mutants of Escherichia coli. J. Bacteriol. 117:1082-1092.

7. Carter, C. J., M. Cannon, and A. Jimenez. 1980. A trichodermin-resistant mutant of Saccharomyces cerevisiae with an abnormal distribution of native ribosomal subunits. Eur. J. Biochem. 107:173-183.

8. Ceretti, D. P., D. D. Dean, G. R. Davis, D. M. Bedwell, and M. Nomura. 1983. The spc ribosomal protein operon of Escherichia coli: sequence and cotranscription of the ribosomal protein genes and a protein export gene. Nucleic Acids Res. 11:25992616.

9. Cigan, A. M., and T. F. Donahue. 1987. Sequence and structural features associated with translational initiator regions in yeast-a review. Gene 59:1-13.

10. Dabbs, E. R. 1986. Mutant studies on the prokaryotic ribosome, p. 733-748. In B. Hardesty and G. Kramer (ed.), Structure, function and genetics of ribosomes. Springer-Verlag, New York.

11. Davis, R. W., D. Botstein, and J. R. Roth. 1980. Advanced bacterial genetics, p. 203. Cold Spring Harbor Laboratory, Cold Spring Harbor, N.Y.

12. Devereux, J., P. Haeberli, and O. Smithies. 1984. A comprehensive set of sequence analysis programs for the VAX. Nucleic Acids Res. 12:387-395.

13. Donahue, T. F., and A. M. Cigan. 1988. Genetic selection for mutations that reduce or abolish ribosomal recognition of the HIS4 translational initiator region. Mol. Cell. Biol. 8:2955-2963.

14. El-Baradi, T. T. A. L., C. A. F. M. Van der Sande, W. H. Mager, H. A. Raue, and R. J. Planta. 1986. The cellular level of yeast ribosomal protein L25 is controlled principally by rapid degradation of excess protein. Curr. Genet. 10:733-739.

15. Fabian, G. R., and A. K. Hopper. 1987. RRPI, a Saccharomyces cerevisiae gene affecting rRNA processing and production of mature ribosomal subunits. J. Bacteriol. 169:1571-1578.

16. Feinberg, B., C. S. McLaughlin, and K. Moldave. 1982. Analysis of temperature-sensitive mutant $t s 187$ of Saccharomyces cerevisiae altered in a component required for initiation of protein synthesis. J. Biol. Chem. 257:10846-10851.

17. Fleming, G., P. Belhumeur, D. Skup, and H. M. Fried. 1989. Functional substitution of mouse ribosomal protein L27' for yeast ribosomal protein L29 in yeast ribosomes. Proc. Natl. 
Acad. Sci. USA 86:217-221.

18. Foiani, M., A. M. Cigan, C. J. Paddon, S. Harashima, and A. G. Hinnebusch. Submitted for publication.

19. Futcher, B., and J. Carbon. 1986. Toxic effects of excess cloned centromeres. Mol. Cell. Biol. 6:2213-2222.

20. Gritz, L. R., J. A. Mitlin, M. Cannon, B. Littlewood, C. J. Carter, and J. E. Davies. 1982. Ribosome structure, maturation of ribosomal RNA and drug sensitivity in temperature-sensitive mutants of Saccharomyces cerevisiae. Mol. Gen. Genet. 188: 384-391.

21. Guthrie, C., H. Nashimoto, and M. Nomura. 1969. Structure and function of $E$. coli ribosomes. VIII. Cold-sensitive mutants defective in ribosome assembly. Proc. Natl. Acad. Sci. USA 63:384-391.

22. Hanic-Joyce, P. J., R. A. Singer, and G. C. Johnston. 1987. Molecular characterization of the yeast $P R T 1$ gene in which mutations affect translation initiation and the regulation of cell proliferation. J. Biol. Chem. 262:2845-2851.

23. Haralson, M. A., and D. J. Roufa. 1975. A temperature-sensitive mutation affecting the mammalian $60 \mathrm{~S}$ ribosome. J. Biol. Chem. 250:4328-4341.

24. Hartwell, L. H., R. K. Mortimer, J. Culotti, and M. Culotti. 1973. Genetic control of the cell division cycle in yeast: V. Genetic analysis of $c d c$ mutants. Genetics 74:267-286.

25. Helser, T. L., R. A. Baan, and A. E. Dahlberg. 1981. Characterization of a $40 \mathrm{~S}$ ribosomal subunit complex in polyribosomes of Saccharomyces cerevisiae treated with cycloheximide. Mol. Cell. Biol. 1:51-57.

26. Henkin, T. M., S. H. Moon, L. C. Mattheakis, and M. Nomura. 1989. Cloning and analysis of the $s p c$ ribosomal protein operon of Bacillus subtilis. Comparison with the $s p c$ operon of Escherichia coli. Nucleic Acids Res. 17:7469-7486.

27. Hinnebusch, A. G. 1988. Mechanisms of gene regulation in the general control of amino acid biosynthesis in Saccharomyces cerevisiae. Microbiol. Rev. 52:248-273.

28. Hofiman, C. S., and F. Winston. 1987. A ten-minute DNA preparation from yeast efficiently releases autonomous plasmids for transformation of Escherichia coli. Gene 57:267-272.

29. Kief, D. R., and J. R. Warner. 1981. Coordinate control of synthesis of ribosomal ribonucleic acid and ribosomal proteins during nutritional shift-up in Saccharomyces cerevisiae. Mol. Cell. Biol. 1:1007-1015.

30. Kimura, J., and M. Kimura. 1987. The complete amino acid sequences of the $5 \mathrm{~S}$ rRNA binding proteins $\mathrm{L} 5$ and L18 from the moderate thermophile Bacillus stearothermophilus ribosome. FEBS Lett. 210:85-90.

31. Kozak, M. 1987. An analysis of 5'-noncoding sequences from 699 vertebrate messenger RNAs. Nucleic Acids Res. 15:81258148.

32. Kozak, M. 1990. Downstream secondary structure facilitates recognition of initiator codons by eukaryotic ribosomes. Proc. Natl. Acad. Sci. USA 87:8301-8305.

33. Kraft, R., J. Tardiff, K. S. Krauter, and L. A. Leinwand. 1988. Using mini-prep plasmid DNA for sequencing double-stranded templates with Sequenase. BioTechniques 6:544-547.

34. Kristiansen, K. (Odense University). 1991. Personal communication.

35. Laemmli, U. K. 1970. Cleavage of structural proteins during the assembly of the head of bacteriophage T4. Nature (London) 227:680-685.

36. Larkin, J. C., J. R. Thompson, and J. L. Woolford, Jr. 1987. Structure and expression of the Saccharomyces cerevisiae CRYl gene: a highly conserved ribosomal protein gene. Mol. Cell. Biol. 7:1764-1775.

37. Leer, R. J., M. M. C. van Raamsdonk-Duin, W. H. Mager, and R. J. Planta. 1984. The primary structure of the gene encoding yeast ribosomal protein L16. FEBS Lett. 175:371-376.

38. Li, H. V., J. Zagorski, and M. Fournier. 1990. Depletion of U14 small nuclear RNA (snR128) disrupts production of 18S rRNA in Saccharomyces cerevisiae. Mol. Cell. Biol. 10:1145-1152.

39. Maicas, E., F. G. Pluthero, and J. D. Friesen. 1988. The accumulation of three yeast ribosomal proteins under conditions of excess mRNA is determined primarily by fast protein decay.
Mol. Cell. Biol. 8:169-175.

40. Marvaldi, J., J. Pichon, and G. Marchis-Mouren. 1979. On the control of ribosomal protein biosynthesis in E. coli. IV. Studies on a temperature-sensitive mutant defective in the assembly of 50S subunits. Mol. Gen. Genet. 171:317-325.

41. Moritz, M., A. G. Paulovich, Y.-F. Tsay, and J. L. Woolford, Jr. 1990. Depletion of yeast ribosomal proteins L16 or rp59 disrupts ribosome assembly. J. Cell Biol. 111:2261-2274.

42. Nam, H. G., and H. M. Fried. 1986. Effects of progressive depletion of TCM1 or CYH2 mRNA on Saccharomyces cerevisiae ribosomal protein accumulation. Mol. Cell. Biol. 6:15351544.

43. Nashimoto, H., A. Miura, H. Saito, and H. Uchida. 1985. Suppressors of temperature-sensitive mutations in a ribosomal protein gene rpsL (S12), of Escherichia coli K12. Mol. Gen. Genet. 199:381-387.

44. Nashimoto, H., and M. Nomura. 1970. Structure and function of bacterial ribosomes. XI. Dependence of 50S ribosomal subunit assembly on simultaneous assembly of 30 S subunits. Proc. Natl. Acad. Sci. USA 67:1440-1447.

45. Nazar, R. N., M. Yaguchi, G. E. Willick, C. F. Rollin, and C. Roy. 1979. The 5S RNA binding protein from yeast (Saccharomyces cerevisiae) ribosomes. Evolution of the eukaryotic 5S RNA binding protein. Eur. J. Biochem. 102:573-582.

46. Nomura, M., P. Traub, C. Guthrie, H. Nashimoto. 1969. The assembly of ribosomes. J. Cell. Physiol. 74:241-252.

47. Ohkubo, S., A. Muto, Y. Kawauchi, F. Yamao, and S. Osawa. 1987. The ribosomal protein gene cluster of Mycoplasma capricolum. Mol. Gen. Genet. 210:314-322.

48. Pearson, W. R., and D. J. Lipman. 1988. Improved tools for biological sequence comparison. Proc. Natl. Acad. Sci. USA 85:2444-2448.

49. Pichon, J., J. Marvaldi, and G. Marchis-Mouren. 1979. On the control of ribosomal protein biosynthesis in $E$. coli. III. Studies on a temperature-sensitive mutant defective in the assembly of 30S subunits. Mol. Gen. Genet. 171:307-316.

50. Pringle, J. R., and L. H. Hartwell. 1981. The Saccharomyces cerevisiae cell cycle, p. 97-142. In J. N. Strathern, E. W. Jones, and J. R. Broach (ed.), The molecular biology of the yeast Saccharomyces: life cycle and inheritance. Cold Spring Harbor Laboratory, Cold Spring Harbor, N.Y.

51. Rose, M. D., and G. R. Fink. 1987. KARI, a gene required for function of both intranuclear and extranuclear microtubules in yeast. Cell. 48:1047-1060.

52. Rotenberg, M. O., M. Moritz, and J. L. Woolford, Jr. 1988. Depletion of Saccharomyces cerevisiae ribosomal protein L16 causes a decrease in $60 \mathrm{~S}$ ribosomal subunits and formation of half-mer polyribosomes. Genes Dev. 2:160-172.

53. Sachs, A. B., and R. W. Davis. 1989. The poly(A) binding protein is required for poly(A) shortening and $60 \mathrm{~S}$ ribosomal subunit-dependent translation initiation. Cell 58:857-867.

54. Sachs, A. B., and R. W. Davis. 1990 . Translation initiation and ribosomal biogenesis: involvement of a putative rRNA helicase and RPL46. Science 247:1077-1079.

55. Schnier, J., and K. Nishi. 1988. Temperature-sensitive mutants with alterations in ribosomal protein L24 and isolation of intraand extragenic suppressor mutants. Methods Enzymol. 164: 706-709.

56. Sherman, F., G. R. Fink, and J. B. Hicks. 1986. Methods in yeast genetics, p. 166-167. Cold Spring Harbor Laboratory, Cold Spring Harbor, N.Y.

57. Sherman, F., and J. W. Stewart. 1982. Mutations altering initiation of translation of yeast iso-1-cytochrome $c$ : contrasts between the eukaryotic and prokaryotic initiation process, $p$. 301-333. In J. N. Strathern, E. W. Jones, and J. R. Broach (ed.), The molecular biology of the yeast Saccharomyces: metabolism and gene expression. Cold Spring Harbor Laboratory, Cold Spring Harbor, N.Y.

58. Singh, A., and T. R. Manney. 1974. Genetic analysis of mutations affecting growth of Saccharomyces cerevisiae at low temperature. Genetics 77:651-659.

59. Singleton, C. K., S. S. Manning, and R. Ken. 1989. Primary structure and regulation of vegetative specific genes of Dictyos- 
telium discoideum. Nucleic Acids Res. 17:9679-9692.

60. Stern, S., T. Powers, L.-M. Changchien, and H. F. Noller. 1989 RNA-protein interactions in $30 \mathrm{~S}$ ribosomal subunits: folding and function of 16S rRNA. Science 244:783-790.

61. Surguchov, A. P., E. S. Fominykch, V. N. Smirnov, M. D. Ter-Avanesyan, L. N. Mironova, and S. G. Inge-Vechtomov. 1981. Further characterization of recessive suppression in yeast. Isolation of the low-temperature sensitive mutant of Saccharomyces cerevisiae defective in the assembly of $60 \mathrm{~S}$ ribosomal subunit. Biochim. Biophys. Acta 654:149-155.

62. Tai, P.-C., D. P. Kessler, and J. Ingraham. 1969. Cold-sensitive mutations in Salmonella typhimurium which affect ribosome synthesis. J. Bacteriol. 97:1298-1304.

63. Tollervey, D., H. Lehtonen, M. Carmo-Fonseca, and E. C. Hurt. 1991. The small nucleolar RNP protein NOP1 (fibrillarin) is required for pre-rRNA processing in yeast. EMBO J. 10:573583.

64. Toniolo, D., H. K. Meiss, and C. Basilico. 1973. A temperaturesensitive mutation affecting 28S ribosomal RNA production in mammalian cells. Proc. Natl. Acad. Sci. USA 70:1273-1277.

65. Tsay, Y.-F., J. R. Thompson, M. O. Rotenberg, J. C. Larkin, and J. L. Woolford, Jr. 1988. Ribosomal protein synthesis is not regulated at the translational level in Saccharomyces cerevisiae: balanced accumulation of ribosomal proteins $\mathrm{Ll6}$ and $\mathrm{rp59}$ is mediated by turnover of excess protein. Genes Dev. 2:664-676.

65a.Tsay, Y.-F., and J. Woolford. Unpublished data.

66. Udem, S. A., and J. R. Warner. 1972. Ribosomal RNA synthesis in Saccharomyces cerevisiae. J. Mol. Biol. 65:227-242.

67. Underwood, M. R., and H. M. Fried. 1990. Characterization of nuclear localizing sequences derived from yeast ribosomal protein L29. EMBO J. 9:91-99.

68. Ursic, D., and J. Davies. 1979. Cold-sensitive mutant of Saccharomyces cerevisiae defective in ribosome processing. Mol. Gen. Genet. 175:313-323.

69. Van der Zeijst, B. A. M., A. J. Kool, and H. P. J. Bloemers. 1972. Isolation of active ribosomal subunits from yeast. Eur. J. Biochem. 30:15-25.

70. Warner, J. R. 1989. The synthesis of ribosomes in Saccharomyces cerevisiae. Microbiol. Rev. 53:256-271.

71. Warner, J. R., G. Mitra, W. F. Schwindinger, M. Studeny, and H. M. Fried. 1985. Saccharomyces cerevisiae coordinates the accumulation of yeast ribosomal proteins by modulating mRNA splicing, translational initiation, and protein turnover. Mol. Cell. Biol. 5:1512-1521.

72. Warner, J. R., and S. A. Udem. 1972. Temperature sensitive mutations affecting ribosome synthesis in Saccharomyces cerevisiae. J. Mol. Biol. 65:243-257.

73. Wittekind, M., J. M. Kolb, J. Dodd, M. Yamagishi, S. Memet, J.-M. Buhler, and M. Nomura. 1990. Conditional expression of RPA190, the gene encoding the largest subunit of yeast RNA polymerase I: effects of decreased rRNA synthesis on ribosomal protein synthesis. Mol. Cell. Biol. 10:2049-2059.

74. Woolford, J. L., L. M. Hereford, and M. Rosbash. 1979. Isolation of cloned DNA sequences containing ribosomal protein genes from Saccharomyces cerevisiae. Cell 18:1247-1259.

75. Zitomer, R. S., D. A. Walthall, B. C. Rymond, and C. P. Hollenberg. 1984. Saccharomyces cerevisiae ribosomes recognize non-AUG initiation codons. Mol. Cell. Biol. 4:1191-1197. 